\title{
MAN, NATURE AND CONSERVATION
}

\author{
D HEY
}

\author{
Director of Nature and Environmental Conservation \\ Cape Province Administration \\ Private Bag X9086 \\ Cape Town \\ 8000
}

I am sure that it is common cause at a gathering such as this that we live in a country of remarkable scenic beauty. Consider for example, our extensive beaches of golden sands, spectacular rocky headlands, rugged mountain chains, vast Karoo's, desert landscapes, rolling grasslands, acacia studded savannas and the unique bushveld where we are gathered today.

Each is characterised by a peculiar flora adapted over the millenia to topography and climate. Acocks (1953) recognises no less than 70 veld types in the Republic of South Africa (RSA), each with its peculiar species and plant associations. Estimates of the number of plant species occurring here vary between 18 thousand and 20 thousand. This is the habitat of our wildlife in its infinite variety and former wealth of numbers. Even though we have lost a great deal, the status of our mammalian fauna still compares very favourably with that of other countries. From the so-called big game animals of Africa to the smallest forms, they still occur in reasonable numbers. The status of our rich avifauna and herpetofauna is, with a few exceptions, sound. The importance of our fauna and flora is further accentuated by the fact that many species are endemic, sometimes to very restricted areas. In fact, herein lies the threat to many species of flora which may disappear due to urban and agricultural development and the intrusion of aliens, which has already reduced the fynbos vegetation to $40 \%$ of its former extent. Apart from its scientific importance, our wildlife is of great interest to the layman. It is by interpreting this to the general public that we can promote conservation, and consequently this aspect may be more important than its scientific value. A basic principle of conservation education is that it must begin with the stimulation of public interest, which leads to appreciation, and thence imperceptibly to a desire to conserve. It is human nature to conserve only those things we appreciate and value.

There are endless examples to illustrate the absorbing interest of our wildlife but time will only permit me to mention two, viz. eels and white pelicans. Upon attaining sexual maturity in our east-flowing rivers, 
adult eels move to the estuaries, and once acclimatised to marine conditions, swim out into the Indian Ocean to spawn. Exactly where and how this occurs is not known, but upon hatching, the larvae drift southwards with the ocean currents to return to the estuaries as elvers and then migrate up the rivers to the headwaters. How even a small percentage of these delicate creatures survive such an epic journey is amazing.

The story of the white pelican of the Etosha Pan in South West Africa is equally remarkable. When the pan started drying up early in the summer of 1971, the flamingoes deserted the breeding area and a flock of white pelicans moved in and started nesting. By the time their chicks commenced hatching, the water had dried up and there was no food. It was then discovered that the adult birds were airlifting food. At $10 \mathrm{~h} 00$ each morning these heavy birds would fly across to Poachers' Point where they would enter a rising air thermal. Here they would circle to an altitude of $3000 \mathrm{~m}$ and then glide to the nearest water some $100 \mathrm{~km}$ distant. They would return the following morning with full crops to feed their young. It was estimated by Berry (1972) who described this fascinating episode, that the adult birds airlifted a total weight of over 700 tons of fish in order to rear their young and nourish themselves.

We are privileged to enjoy this rich and interesting wildlife heritage, but privilege brings with it responsibility, a responsibility not only to our fellow citizens but also to those who come after us. Looking at the situation elsewhere, and in the light of developments around us, I believe that we have not only a national but also an international responsibility to conserve the unique wildlife of southern Africa - for wildlife today must be regarded as an international asset.

We in the Cape Department of Nature and Environmental Conservation interpret conservation as meaning wise management of these resources in the spirit of good stewardship. Management may embrace a wide spectrum of activities from total protection to culling surplus animals and veld burning. I have no doubt that the authorities concerned, including the National Parks Board, the Provincial Administrations and some State Departments are fully alive to their responsibilities. This conservation effort is ably supported by organisations such as the Council for Scientific and Industrial Research, museums, universities, and private societies and we will undoubtedly hear more of this good work in later papers. All nature conservation activities in the RSA are co-ordinated at provincial level by the Interprovincial Technical Committee for Nature Conservation (TECNAC) and at national level by the National Committee for Nature Conservation (NACOR) and the Council for the Environment. Considering that the conservation effort in the RSA is 50 years old at most, and has only really gained impetus during the past 20 years, I believe that we have made remarkable progress.

Nevertheless, there are no grounds for complacency. It is always a 
healthy exercise to ask ourselves periodically - what are we trying to achieve and are we setting about it in the right way? Looking at the present situation objectively, I sometimes wonder whether it might not be a case of just winning battles, and that we may find ourselves losing the war in the long run.

After a lifetime devoted to conservation I see two very basic and real problems looming ever larger in the future, viz. human numbers and perhaps even more important, human attitudes. The question of human numbers has been dealt with adequately by Vollmar (1977) in his keynote address. In essence it is predicted that if present trends continue, the world population of 4000 million will double by the turn of the century.

More significant, however, is the alaraming rate of population increase. Whereas it required 200000 years to reach the first 1000 million, the fourth 1000 million was added to the world population in only 15 years. In the RSA the rate of increase in even higher for it is predicted that our present population of 25 million will rise to between 60 and 70 millions by the year 2000 . This will require almost a tripling of services such as food production, water, housing and electricity within a mere 25 years, which must have a tremendous impact on the natural resources and appearance of our country. Suggesting solutions to this involved and difficult problem is fortunately not the purpose of this paper. I merely spotlight the problem which must be solved to prevent over-population of the good earth and also leave some room for wildlife. If not, the future for both wildlife and man will be dismal.

Equally important is a radical change in human attitudes towards wildlife resources. Unless this problem is also solved, there is little hope for the future. The majority seem to regard it as a right to exploit wildlife resources in any form whatsoever. In the pioneer days it started with ivory, hides and meat and as these resources became exhausted, man turned to other forms to "make a quick buck". Today butterfly wings are an article of commerce and some species are already endangered. What will be exploited next? This "free for all" attitude towards nature seems to permeate all our activities as evidenced by the pollution of rivers, sea and air, littering of public places and acts of vandalism. It all adds up to the eventual desecration of nature and total degradation of our environment. My plea, therefore, is for a very decided change of heart leading to what may be termed a new code of outdoor conduct. This must be tempered with a little reverence for life and a recognition of the right of wild creatures to inhabit this earth. It must involve a willingness to share not only with our fellow man but with generations to come. This is nature conservation in the spirit of true stewardship.

In order to change attitudes towards wildlife, it is interesting to consider very briefly some attitudes in the past. In the early days man lived as a gatherer-hunter. His numbers were few and nature was vast and consequently he made little impact on wildlife resources. Neverthe- 
less, his actions were seldom wasteful. He hunted for his needs only and utilised most parts of the animals he killed. He considered himself one with nature which he both feared and respected. The bitter conflict between European immigrants with their philosophy of ownership, and the plains Indians of North America with their belief in communal hunting grounds is a sad story and an indictment of our so-called civilisation.

The early Greeks had a profound respect of nature although this was somewhat clouded by superstitions and mysticism. To them the universe was an indivisible whole, a Koinonia. It is also interesting to note that Plato, as early as $400 \mathrm{BC}$, predicted the degradation of the Grecian landscape due to indiscriminate tree felling and agricultural malpractices.

The Judaeo-Christians attitude, which incidentally forms our background, was that the earth is here to serve man. The command in Genesis 1:28 to subdue and have dominion was interpreted literally, with resultant general exploitation of nature. However, I submit that although Genesis 1:28 sets man above nature, this should be interpreted in conjunction with Genesis 1:31 viz. that the Almighty found His creation good and in terms of Genesis 2:15 placed man in the garden "to dress and keep it". This implies good stewardship or good management and certainly not licence to plunder and destroy. It is not the teaching of the Bible which is at fault, but man's incorrect interpretation thereof. It was unfortunately in the spirit of "subdue and have dominion" that European man colonised the New World, and this still persists today in the attitude of many towards our natural resources. Conservation is a fairly recent concept, and although gaining impetus rapidly, its proponents are far in the minority. There are many who say, "If the great auk and the quagga are extinct - so what? We can do without them". There are others who place their faith in man's ingenuity and technology, which they believe will meet any threats to his future. Then there are those who are as yet completely oblivious to the gravity of the situation. A leading African expressed the view recently that if he limited his family, he would be denying his children the benefits of present day civilisation. "In the days of our forefathers" he said, "my people suffered from periodical famines, and our numbers were depleted by wars and pestilence. Today we need never go hungry and epidemics are a thing of the past. We also enjoy the benefits of modern technology. It would be selfish to deny children these pleasures!"

Rachel Carson was one of the first to draw attention to the fact that nature conservation has a wider implication than the survival of animal species. She stated:

"Man's attitude towards nature is today critically important simply because we have now acquired a fateful power to alter and destroy nature. But man is a part of nature and his war against nature is inevitably a war against himself' (Brooks 1973). 
The work of Rachel Carson focussed public attention on the world of nature and resulted in a tremendous upwelling of concern regarding the threat of pollution to wildlife and the human environment. This reached the stage in America where it became almost embarrassing for the professional conservationists. Recently theologians have also become involved, partly as a result of the charges laid at the door of Christian teaching. The modern view is aptly summed up by Taylor (1975):

"Yesterday ecology was regarded as a science. Today it is becoming a social necessity. Tomorrow it had better become a part of our religion if, to use the language of the young "we are to keep making the scene". Perhaps we need an eleventh commandment: "Thou shalt learn to live on a planet and keep it whole".

In conclusion, I submit that there is no single or simple solution to the problem of conserving our remaining wildlife resources and the natural environment. This can only be achieved by a multiple approach including the economic elements outlined by Vollmar (1977). In the RSA we are already moving along these lines with the farming of wild flowers, including possible cropping in wild flower reserves, game ranching and trophy hunting on farms. I cannot, however, reject the aesthetic and ethical elements on which the conservation ethic is based as I believe these to be the hallmark of a cultured people. With diminishing nature and increasing human numbers we must learn to live will all forms of wildlife not incompatible with our health or activities. Collectively, farms are becoming the most important habitat for wildlife and therefore the role of the landowner in the conservation effort cannot be overemphasised. Many forms of wildlife have also adapted themselves to city gardens. I was impressed by an article by Owen and Owen (1975) where the importance of gardens as a habitat for smaller forms if wildlife was stressed. Gardens by their very nature provide for richer feeding and in greater variety than any natural habitat. Collectively, gardens in Britain cover a greater area than all proclaimed nature reserves and can therefore make an appreciable contribution to the total conservation effort.

To encourage this new approach towards wildlife will involve both a massive educational programme and more stringent law enforcement. As there are papers at this symposium dealing with both education and interpretation I will not dwell on this subject and will merely mention two aspects in passing. Firstly, our South African efforts in the past have been directed largely towards our white population. We must now devote more attention to the other racial groups. This does not simply mean translating the material we have used to date, but involves a completely new approach. Interpretation is only effective when related within the personal background and experience of the group. Secondly, the recent introduction of television provides a powerful new medium 
whereby we can reach the unconverted - an opportunity we have never enjoyed before. Efforts to provide an adequate system of national parks, nature reserves (including species reserves, subsidised reserves and private reserves) must be intensified while land is still available. Each of these is an important component in the total conservation effort as will be shown by later speakers.

To relieve the increasing human pressure on our parks, reserves and wilderness areas much more attention must be given to the recreational needs of man. In the past we have been inclined to regard the RSA as a vast country and we enjoyed our recreation in the open veld. Today not only is the population far larger, but new types of recreation have been introduced - in themselves perfectly legitimate, but incompatible with most other forms. Special areas should now be reserved for activities such as speedboating, skiing and scrambling, which cannot be permitted in nature reserves. We have also lagged far behind European countries in providing adequate city parks. For both his physical and spiritual health it is essential that the city child be given the opportunity of sensing the feel of grass underfoot and resting his eyes on green trees and blue sky.

I believe that with proper planning, positive and determined action and correct attitudes we can conserve our priceless wildlife heritage, if this problem is approached in the spirit of true stewarship.

\section{REFERENCES}

ACOCKS, J P H 1953. Veld types of South Africa. Mem. bot. Surv. S. Afr. 28.

BERRY, H.H B 1972. Pelicans airfreight their fish 100 kilometres. Afr. Wildlife 26(3).

BROOKS, P 1973. The House of Life. London: George Allen and Unwin.

OWEN, J and D F OWEN 1975. Suburban gardens - England's most important nature reserve? Environmental Conservation 2(1):53.

TAYLOR, J U 1975. Enough is Enough. London: SCN Press.

VOLLMAR, F 1977. Conserving One Earth. A Look at World Conservation. Supplement to Koedoe. 1977: 10-23. 